480

http://dx.doi.org/10.1590/0100-2945-112/14

\title{
THE LYCHEE TREE PROPAGATION BY LAYERING ${ }^{1}$
}

\author{
LEILA CRISTINA ROSA DE LINS², LUIZ CARLOS CHAMHUM SALOMÃO ${ }^{3}$, \\ PAULO ROBERTO CECON ${ }^{3}$, DALMO LOPES DE SIQUEIRA ${ }^{3}$
}

\begin{abstract}
The aim of the study was to assess the influence of season and different substrates on rooting of air layers of lychee (Litchi chinensis Sonn.) for the production of seedlings to ensure the formation of uniform and productive orchards. Air layers were done in plants of the Bengal cultivar using leafy and healthy woody branches, with about 0.010 to $0.015 \mathrm{~m}$ in diameter, in which were performed complete girdling with $0.020 \mathrm{~m}$ wide at a distance of 0.30 to $0.40 \mathrm{~m}$ below the apex. Then the branches were wrapped in moistened substrate. The layering was made at six times of the year (January, March, May, July, September and November) and two substrates were used (coconut fiber and sphagnum) in a $6 \times 2$ factorial design in a randomized block with ten replicates. After 90 days, layers were separated from the matrix plant and evaluated for rooting and callus formation, root number, considering only the primary roots, length, area and volume of the roots, beyond the dry weight of roots and calluses. The months of January, March, September and November showed the best results for all analyzed variables related to rooting. With respect to the substrates, the only difference was in January and March to the root number and dry weight of roots, where the sphagnum showed the best results. The month of July was more conducive to the formation of calluses. The period between September and March was more suitable to the propagation of lychee, when there were rooting percentages above $90 \%$, in addition to the formation of large amount of roots.
\end{abstract}

Index terms: Litchi chinensis Sonn., rooting, substratum.

\section{PROPAGAÇÃO DA LICHIEIRA POR ALPORQUIA}

RESUMO - O objetivo do trabalho foi verificar a influência da época do ano e de diferentes substratos no enraizamento de alporques de lichieira (Litchi chinensis Sonn.), visando à produção de mudas que assegurem a formação de pomares uniformes e produtivos. Foram feitos alporques em plantas da cultivar Bengal utilizando ramos lenhosos bem enfolhados e sadios, com cerca de 0,010 a 0,015 m de diâmetro, nos quais foram realizados anelamentos completos de $0,020 \mathrm{~m}$ de largura, a uma distância de 0,30 a 0,40 m abaixo do ápice dos mesmos. A seguir, os ramos foram envoltos por substrato umedecido. Foram avaliadas seis épocas de realização dos alporques (janeiro, março, maio, julho, setembro e novembro) e dois substratos (esfagno e fibra de coco), em um esquema fatorial 6 × 2, no delineamento em blocos casualizados, com dez repetições. Passados 90 dias, os alporques foram separados da planta-matriz e avaliados quanto à porcentagem de enraizamento e de calejamento; número de raízes, considerando-se apenas as raízes primárias; comprimento, área e volume das raízes; além da massa seca de raízes e calos. Os meses de janeiro, março, setembro e novembro apresentaram os melhores resultados para todas as variáveis relacionadas ao enraizamento analisadas. Com relação aos substratos, houve diferença apenas nos meses de janeiro e março para o número de raízes e massa seca de raízes, onde o esfagno apresentou os melhores resultados. No mês de julho, houve maior formação de calos. O período compreendido entre os meses de setembro e março foi o mais propício à propagação da lichieira, quando se obtiveram porcentagens de enraizamento superiores a 90\%, além da formação de grande quantidade de raízes.

Termos para Indexação: Litchi chinensis Sonn., enraizamento, substrato.

\footnotetext{
${ }^{1}$ (Trabalho 112-14). Recebido em : 10-11-2014. Aceito para publicação em : 28-03-2015 .

${ }^{2}$ Department of Plant Science, Federal University of Viçosa, PH Rolfs Av, s / n, CEP: 36570-000, Viçosa, Minas Gerais, Brazil. E-mail: leila.lins@ufv.br

${ }^{3} \mathrm{CNPq}$ Researcher. Department of Plant Science, Federal University of Viçosa, PH Rolfs Av, s / n, CEP: 36570-000, Viçosa, Minas Gerais, Brazil. E-mails: 1salomao@ufv.br; cecon@ufv.br; siqueira@ufv.br

Financial support: $\mathrm{CNPq}$
}

Rev. Bras. Frutic., Jaboticabal - SP, v. 37, n. 2, p. 480- 487, Junho 2015 


\section{INTRODUCTION}

The lychee (Litchi chinensis Sonn.), species of Sapindaceae family, has as the center of origin the region between southern China and northern Vietnam, where it is cultivated for over 3,000 years. In Brazil, the lychee was introduced in the late XIX century and only in the last decade of the XX century the fruit began to be produced for commercial purposes (YAMANISHI et al., 2010).

Cultivation of lychee has aroused growing interest in the country, due to increased demand in the retail market. For Yamanishi et al. (2010), the lychee has great potential to become a popular fruit in Brazil. One factor in favor of Brazil is that the production of lychee occurs in the months from November to January, when demand for the fruit is high and there is no competition with other countries.

In despite of good prices in domestic and international market, there is still resistance to increase the number and size of lychee orchards. Brazilian production is still restricted to small plantations and isolated plants, one of the major problems for the increased production of lychee in Brazil is the fact that there are few studies that can provide security for producers, making difficult the deployment of a system of production of quality seedlings (TAKATA et al., 2011).

The lychee tree can be propagated in several ways, being layering the most appropriate (CASTRO and SILVEIRA, 2003). The layering technique is also known as air layering and consists in inducing rooting of the branch, yet tied to the mother plants by means of a complete girdling with the removal of the cortex, followed by the involvement of the girdled region with moistened substrate (BITENCOURT et al., 2007). The girdling causes photoassimilates and hormones transported by the phloem to be retained in the region of the layers and show increasing nutrient availability to new root formation (HARTMANN et al., 2011).

According to Castro and Silveira (2003), the propagation by layering has advantages over other methods, such as the high percentage of rooting, independence of infrastructure and shorter juvenility, besides the homogeneity of the seedlings and the possibility of choice of plants with higher fruit production.

Rooting is affected by internal factors, such as physiological conditions, the age of the mother plant and hormonal balance, and external factors, such as temperature, light, humidity and substrate (HARTMANN et al., 2011; RIOS et al., 2012).

The period of the year is an important factor influencing the rooting of air layer, it is directly related to the physiological condition of the mother plant and its stages of development, thus interfering with the production of growth-promoting substances. The most appropriate period for the implementation of layering is from spring until late summer, when the metabolic functions of the plant are in full activity, so that there is great synthesis and storage of carbohydrates, important in the formation of roots (HARTMANN et al., 2011).

The substrate is another relevant factor to the emission and root development. Boechat et al. (2010) reported that a good substrate is that which provides optimum conditions for good root growth, such as porosity and water holding capacity.

To increase both the production and cultivation areas, it is necessary to have studies related to the production of seedlings with good genetic quality and plant health, and being homogeneous to facilitate orchard management. Thus propagation conducted at appropriate time of year, coupled with the use of a good substrate, can optimize the production of lychee plants to ensure the formation of uniform and highly productive orchards whose fruits exhibit defined patterns, which enable its marketing such as fresh fruit.

The aim of this study was to investigate the influence of different seasons and two substrates on rooting of airs layers of Litchi chinensis Sonn, cultivar Bengal, to obtain seedlings for commercial cultivation.

\section{MATERIAL AND METHODS}

The experiment was arranged in the experimental orchard of the Department of Plant Science of the Federal University of Viçosa, Minas Gerais $\left(21^{\circ} 07 \mathrm{~S}, 42^{\circ} 57 \mathrm{~W}, 651 \mathrm{~m}\right.$ altitude), using, as mother plants, 'Bengal' lychee trees with 8 years old at the start of the experiment. Selected plants were homogeneous regarding size and phenological state, with $4.5 \mathrm{~m}$ height and crown diameter near to $7 \mathrm{~m}$ on average.

Six seasons of layering, held in May, July, September and November 2011 and January and March 2012, and two substrates, the sphagnum and coconut fiber Amafibra ${ }^{\circledR}$, developed from the mesocarp of the coconut, which combines granular portion $(50 \%)$ with its fiber $(50 \%)$ were evaluated.

For the fabrication of the air layers, leafy and healthy woody branches with about 1.0 to 0.015 $\mathrm{m}$ in diameter, with the last outbreak of mature growth were used. The air layers were distributed in the middle third, in branches scattered in the four 
quadrants of the plant. In the stages of flowering and fruiting the air layering was performed in branches without flowers or fruits.

In the branches were performed complete girdling with $0.02 \mathrm{~m}$ wide at a distance of 0.30 to $0.40 \mathrm{~m}$ below the apex, with the aid of a doublebladed knife. The bases of the layers were covered with about $200 \mathrm{~mL}$ of wet substrate, which provided that the coverage of $0.05 \mathrm{~m}$ above and $0.05 \mathrm{~m}$ below the gird. The girdle branches with the wet substrate were then involved with transparent polyethylene films, closed at both ends, with the use of string for support of the substrate and maintenance of the humidity around the gird and, at the same time, the group was also wrapped in aluminum foil, which favored the development of roots.

The substrates were moistened, keeping the ratio of 1:6(w:w) for the sphagnum and 1:2.5 (w:w) for coconut fiber, or in the case of sphagnum $600 \mathrm{~mL}$ of water were used to moisten the $100 \mathrm{~g}$ of substrate and for the coconut fiber per $100 \mathrm{~g}$ of substrate 250 $\mathrm{mL}$ of water were used. The amount of water used to moisten the substrates was determined according to their retention capacity. The need for water replacement in the substrate was evaluated in extra layers, made exclusively for this purpose, which were checked at intervals of 15 days. When necessary, replacement of water was made, using syringe.

After 90 days of the layering, layers were separated from the mother plant with a cut about 0.10 $\mathrm{m}$ below the gird and carried to the laboratory where the removal of the aluminum foil and polyethylene film was made. The substrate was carefully removed with tap water for washing the roots, and then it was made a cut in the region of the ring for removing the top of the stem. The roots were superficially dried and then evaluations were made.

We evaluated the percentage of rooting and callus from the count of total rooted and calloused layers in each period, respectively. It was determined the number of roots, counting only primary roots, i.e., those arising directly from the branch in which it was made the layering. It was also determined the dry mass of roots and callus after drying in an drying oven with forced air circulation for 72 hours at $70^{\circ} \mathrm{C}$.

Furthermore, we assessed length, area and volume of the roots by means of image analysis, the WinRHIZO software Pro 2009c (Regent Instruments Inc., Quebec, Canada) coupled to XL 10,000 Epson Expression scanner (EPSON São Paulo, Brazil, SP), equipped with additional light (TPU) with resolution of 400 dpi, as described by Bouma et al. (2000).

The experiment was conducted in a factorial $6 \times 2$ (6 periods of the year $\times 2$ substrates), in a randomized block design. The experiment consisted of ten blocks (mother plants), with four layering by each plant in each period of the year (two layers with sphagnum and two with coconut fiber). In each mother plant, 24 layers were made, totaling 240 layers in the end of the experiment.

The data were subjected to analysis of variance and means were compared by Tukey test at 5\% probability, using the program SAEG 9.1 - System for Genetic Analysis and Statistics. Regardless of the interaction time and substrate be significant or not, it was chosen its deployment, for the interest of the study. For percentage data, descriptive analysis was done.

\section{RESULTS AND DISCUSSION}

Considering all the experimental period, rooting percentages higher than $90 \%$ in $75 \%$ of observations were observed (Figure 1). The layering made in July had the lowest percentages of rooting for both substrates, with 83 and $25 \%$ for the sphagnum and coconut fiber, respectively. The rooting percentage inferior to $100 \%$ is due to the presence of layering just calloused or absence of callus and roots, not being observed death of layering. The high values of percentage of rooting, with the exception of layering made in the months of May and July, confirm the potential of using the layering method for propagation of lychee.

The higher values for number of primary roots, i.e., those arising from the layer, were obtained in layering made in the months of September and November for coconut fiber; for layering made with sphagnum, this period is also extended to January and March (Table 1).

For the dry matter of roots, the mean values observed in layering made in the months of September and November showed no significant differences for both substrates (Table 1). For layering made from sphagnum, the average dry mass of roots observed in January and March showed similar means to September and November. This fact is an indication that the sphagnum was superior to coconut fiber, since its use provided better results over longer periods.

Phenological stages of 'Bengal' lychee can be described according to the observations during the experimental period, as follows: growth of vegetative flow responsible for the flowering occurs from March, in July there is the emergence of inflorescence, anthesis occurs in September and complete fruit ripening at the end of December. The best results of rooting were observed in layering 
made in the months of September and November, when the plants were in fructification. According to Hartmann et al. (2011), the most appropriate period for the implementation of layering runs from early spring until late summer, when the metabolic functions of the plant are in full activity and there are great synthesis and storage of carbohydrates.

Carbohydrates are source of carbon and energy for the biosynthesis of nucleic acids and proteins, and other substances essential to the formation of roots (LIMA et al. 2011). One should take into account the fact that the layering need to be integrally connected to the mother plant for all rooting time and that their behavior reflects what happens in the various phases.

According to Batten and Lahav (1994), the vegetative growth of lychee is favored at temperatures between 20 and $35^{\circ} \mathrm{C}$, with optimum around $30^{\circ} \mathrm{C}$. Therefore, we can deduce that the low rooting percentage, besides the formation of fewer roots and achievement of their lower mass in the months of May and July, is related to the fact that layering have been developed in months of lower temperatures.

According to Hartmann et al. (2011), cell division is favored by raising the temperature, thus it helps the formation of roots and sprouts production. In addition, the months between September and March there is a water balance favorable, with high rainfall and high humidity. However, low temperatures decrease the metabolism, leading to lower production of shoots and the longest time for rooting, or even do not provide suitable conditions to induction, development and root growth to occur.

According to Porlings e Therios (1976), cited by Almeida et al. (2004), light intensity and photosynthesis vary with the season and may contribute to rooting, but there is evidence that additional factors, such as mineral nutrition and hormonal balance and water, are involved with the fluctuation of the response to rooting.

The formation of adventitious root is a complex process and dependent on factors such as the level of endogenous growth regulators, presence of carbohydrates, presence or absence of dormant buds and emergence of shoots (SMART et al., 2003). According to Hartmann et al. (2011), adventitious roots in cuttings of plants with secondary growth originating from the young tissue of the phloem, vascular rays, vascular cambium or callus produced at the base of the cuttings. The process of development of adventitious roots in cuttings is similar to its development in layers, whereas a layering can be considered a cutting still attached to the mother plant.
There was interaction between the factors time x substrate in the months of January and March, for the variables number of roots and dry mass of roots, with the highest averages for both parameters being obtained with sphagnum. In the other months there were no differences between the substrates (Table 1).

Unlike observed in this experiment, when comparing substrates Plantmax ${ }^{\circledR}$, humus and sphagnum on rooting of layers of 'Bengal' lychee, conducted between October and January, Smarsi et al. (2008) the worst results were obtained for sphagnum, reaching $96 \%$ of rooting only with the use of 2.000 mg L ${ }^{-1}$ IBA.

Lima et al. (2008), studying the effect of IBA doses on different substrates on the layering of Maytenus muelleri, did not obtain rooting for any of the tested substrates, including coconut fiber and sphagnum. It can be inferred, therefore, that different species show different responses to different substrates.

In the present study, when there was difference between the tested substrates, sphagnum showed the best results, yielding percentage of rooting 100\% without the use of growth regulators.

It was found that the sphagnum has a higher capacity of retaining water plus high aeration capacity when compared to coconut fiber. This fact probably influenced the best results obtained for this substrate.

For the length, surface and root volume, the lowest averages were obtained when layering was made in the months of May and July, regardless of the substrate (Table 2). When using sphagnum as substrate, there were no differences with respect to the total length, surface and volume of roots in the months of January, March, September and November. For the coconut fiber, the highest values for length and surface were recorded during September and November, and root volume for this substrate did not differ in March, September and November (Table 2).

The root length determines the ability of the plant to adapt to stress conditions, because longer roots have been associated with high efficiency to assimilate water and nutrients from the soil (RUIZSÁNCHEZ et al., 2005). Thus, longer roots are associated with increased survival in field conditions. It should be emphasized, too, that the root volume presented by layers is of great importance in the lychee propagation. According to Franco et al. (2005), the largest root volume is indispensable to ensure successful installation of the orchard, as it increases the rate of fixation and survival of plants in the field. 
In layering made in May and July, periods of less rooting, there was a higher percentage of calloused layers in both tested substrates (Figure 2). In September we verified the smallest percentage of callus using coconut fiber (8\%); when using sphagnum in the same month, $100 \%$ of the layering showed callus. With the use of coconut fiber it was found the largest and also the lowest dry mass of callus, 2.58 and $0.02 \mathrm{~g}$ in the months of July and September, respectively. In relation to sphagnum these values were 1.71 and $0.24 \mathrm{~g}$ in the months of July and November, respectively (Table 1). In general, one can consider that the callus was more intense in the month of July, when there was $100 \%$ of layers with calluses and these exhibited higher dry mass when compared to the others, regardless of the substrate evaluated.

Smarsi et al. (2008) evaluating the effect of IBA and different substrates on vegetative propagation of lychee by layering, found lower callus when used sphagnum compared to Plantmax ( $)$ and humus. In that study, the highest percentage of callus for sphagnum was $93 \%$ at a dose of $2000 \mathrm{mg} \mathrm{L}^{-1}$ IBA. At this same dose of IBA, the percentage of callus formation was $100 \%$ for all other substrates evaluated. Lima et al. (2008), studying the substrates sphagnum, coconut fiber and vermiculite in propagation by layering of "espinheira-santa" (Maytenus muelleri), found that the percentage of layers with callus was significantly higher when used coconut fiber $(49 \%)$, while the sphagnum provided a smaller percentage of layers with callus (13\%).

According to Hartmann et al. (2011), callus formation precedes the formation of adventitious roots in some species, but in most species these are independent processes, being the simultaneous occurrence due to the dependence of similar internal and environmental conditions. In this study, in the months in which there were less rooting (May to July), the calluses were more developed, which may indicate that formation of roots in layering of lychee is independent of callus formation, or the presence of callus is not a precursor of initiation of roots, both are events that occur independent of one another. Thus, it can be inferred that the performance of the layering of lychee in the months of May and July represent a metabolic cost to the plant, there is little root formation and intense callus formation.

The wound made at the time of girdling contributes to the formation of callus. According to Hartmann et al. (2011), cellular activity in the injured area is stimulated by increased respiratory rate and increase in the levels of auxins, carbohydrates and ethylene, stimulating callus and root formation.

TABLE 1 - Root number (RN), dry mass of roots (DMR) and dry mass of callus (DMC) per layer in lychee 'Bengal' trees with layering made in different periods with different substrates. Viçosa - MG, May 2011 to March 2012.

\begin{tabular}{ccccccc}
\hline \multirow{2}{*}{ Month } & \multicolumn{2}{c}{ RN } & \multicolumn{2}{c}{ DMR $(\mathrm{g})$} & \multicolumn{2}{c}{ DMC $(\mathrm{g})$} \\
\cline { 2 - 7 } & Sphagnum & Coconut fiber & Sphagnum & Coconut fiber & Sphagnum & Coconut fiber \\
\hline January & $29.30 \mathrm{aA}$ & $13.60 \mathrm{bB}$ & $0.98 \mathrm{aA}$ & $0.62 \mathrm{bB}$ & $0.26 \mathrm{bA}$ & $0.37 \mathrm{bcA}$ \\
March & $39.35 \mathrm{aA}$ & $18.35 \mathrm{bB}$ & $0.94 \mathrm{aA}$ & $0.61 \mathrm{bB}$ & $0.72 \mathrm{bA}$ & $0.50 \mathrm{bcA}$ \\
May & $9.65 \mathrm{bA}$ & $7.00 \mathrm{bA}$ & $0.09 \mathrm{bA}$ & $0.03 \mathrm{cA}$ & $0.73 \mathrm{bA}$ & $0.86 \mathrm{bA}$ \\
July & $7.75 \mathrm{bA}$ & $3.92 \mathrm{bA}$ & $0.03 \mathrm{bA}$ & $0.09 \mathrm{cA}$ & $1.71 \mathrm{aB}$ & $2.58 \mathrm{aA}$ \\
September & $39.75 \mathrm{aA}$ & $47.19 \mathrm{aA}$ & $1.02 \mathrm{aA}$ & $1.03 \mathrm{abA}$ & $0.75 \mathrm{bA}$ & $0.02 \mathrm{cB}$ \\
November & $41.65 \mathrm{aA}$ & $33.25 \mathrm{aA}$ & $1.27 \mathrm{aA}$ & $1.15 \mathrm{aA}$ & $0.24 \mathrm{bA}$ & $0.50 \mathrm{bcA}$ \\
\hline CV $(\%)$ & \multicolumn{2}{c}{46.69} & \multicolumn{2}{c}{51.32} & \multicolumn{2}{c}{58.51} \\
\hline
\end{tabular}

* Means followed by the same lowercase in the column and uppercase in the line for the same variable are not statistically different at $5 \%$ probability by Tukey test. 
TABLE 2 - Root length, surface and volume of layers of lychee 'Bengal' made in different periods with different substrates. Viçosa - MG, May 2011 to March 2012.

\begin{tabular}{|c|c|c|c|c|c|c|}
\hline \multirow{2}{*}{ Months } & \multicolumn{2}{|c|}{ Length $(\mathrm{cm})$} & \multicolumn{2}{|c|}{ Surface $\left(\mathrm{cm}^{2}\right)$} & \multicolumn{2}{|c|}{ Volume $\left(\mathrm{cm}^{3}\right)$} \\
\hline & Sphagnum & Coconut fiber & Sphagnum & Coconut fiber & Sphagnum & Coconut fiber \\
\hline January & $618.02 \mathrm{aA}$ & $548.83 \mathrm{bcA}$ & $222.24 \mathrm{aA}$ & $140.51 \mathrm{bB}$ & $7.73 \mathrm{abA}$ & $2.9810 \mathrm{bcB}$ \\
\hline March & $579.17 \mathrm{aA}$ & $321.85 \mathrm{cdB}$ & $204.97 \mathrm{aA}$ & $128.51 \mathrm{bcB}$ & $10.75 \mathrm{aA}$ & $5.3901 \mathrm{abB}$ \\
\hline May & $56.46 \mathrm{bA}$ & $17.69 \mathrm{eA}$ & $25.61 \mathrm{bA}$ & $8.33 \mathrm{dA}$ & $0.63 \mathrm{cA}$ & $0.1130 \mathrm{cA}$ \\
\hline July & $201.17 \mathrm{bA}$ & $119.46 \mathrm{deA}$ & 85.69 bA & $30.81 \mathrm{cdA}$ & $2.80 \mathrm{bcA}$ & $0.0511 \mathrm{cA}$ \\
\hline September & $695.59 \mathrm{aA}$ & $603.03 \mathrm{abA}$ & $279.56 \mathrm{aA}$ & $238.62 \mathrm{aA}$ & $11.74 \mathrm{aA}$ & $9.0967 \mathrm{aA}$ \\
\hline November & $677.86 \mathrm{aA}$ & $830.07 \mathrm{aA}$ & $277.71 \mathrm{aA}$ & $274.29 \mathrm{aA}$ & $10.74 \mathrm{aA}$ & $8.5103 \mathrm{aA}$ \\
\hline $\mathrm{CV}(\%)$ & \multicolumn{2}{|c|}{46.84} & \multicolumn{2}{|c|}{47.19} & \multicolumn{2}{|c|}{66.03} \\
\hline
\end{tabular}

* Means followed by the same lowercase in the column and uppercase on the line for the same variable are not statistically different at $5 \%$ probability by Tukey test.

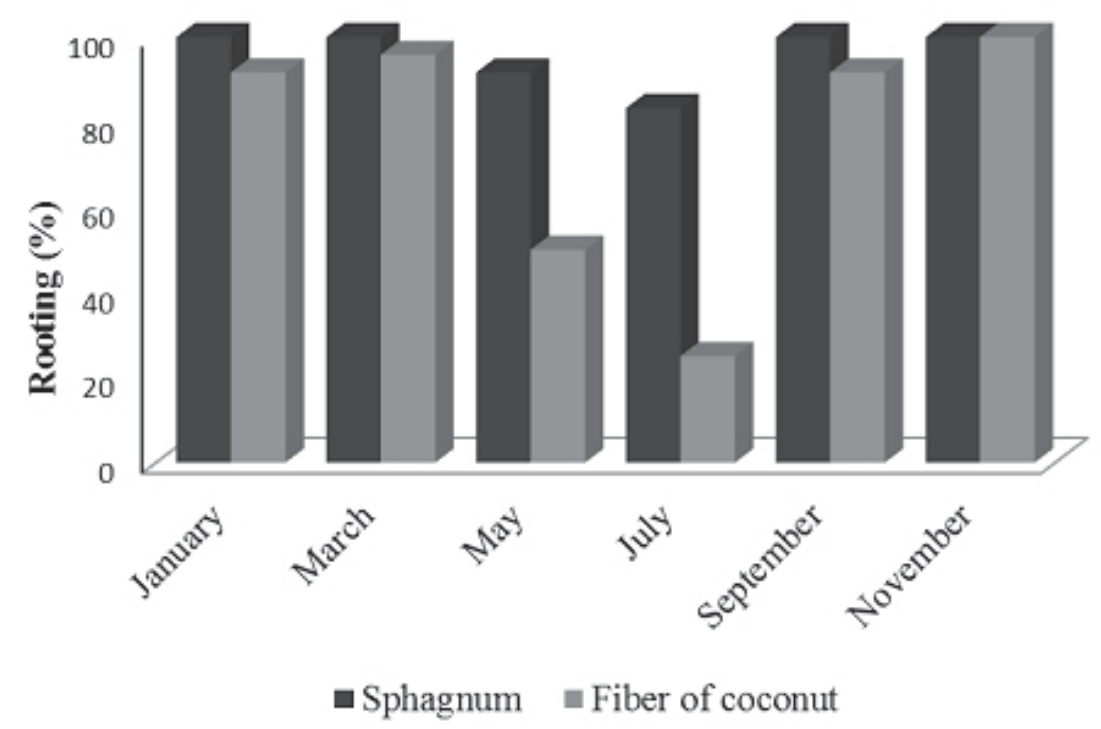

FIGURE 1 - Percentage of rooted layers in lychee 'Bengal' with layering made in different seasons with different substrates. Viçosa - MG, May 2011 to March 2012. 


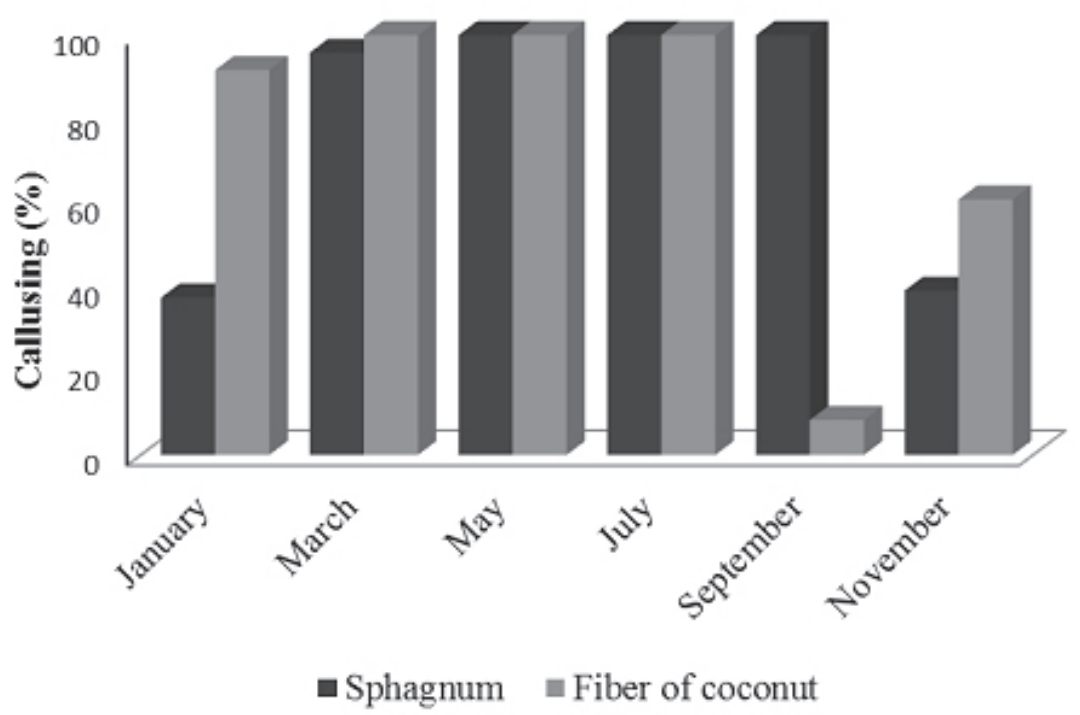

FIGURE 2- Percentage of layers with callus in lychee 'Bengal', with layering made in different seasons with different substrates. Viçosa - MG, May 2011 to March 2012.

\section{CONCLUSIONS}

The layering in lychee, cultivar Bengal, when held in the spring and summer provides the best results of rooting, verified by the high percentage of rooted layers, as well as by higher mass, length, surface and volume of roots.

Sphagnum has the best results of rooting during the year, compared to the coconut fiber. However, when the layering of lychee is held between the months of September and November, coconut fiber can be used as substrate, obtaining good results of rooting.

\section{ACKNOWLEDGMENT}

To the Department of Plant Science of the Federal University of Viçosa and to CNPq, for scholarship, and to Dr. Rogério Vieira, researcher from the Empresa de Pesquisa Agropecuária de Minas Gerais - EPAMIG, for the loan of equipment for measuring roots.

\section{REFERENCES}

ALMEIDA, E. J.; JESUS, N.; GANGA, R. M. D.; BENASSI, A. C.; SCALOPPI JÚNIOR, E. J.; MARTINS, A. B. G. Propagação de Dovyalis sp. pelo processo de mergulhia aérea. Revista Brasileira de Fruticultura, Jaboticabal, v. 26, n. 3, p.511-514, 2004.

BATTEN, J. D.; LAHAV, E. Base temperatures for growth processes of lychee, a recurrently flushing tree, are similar but optima differ. Australian Journal of Plant Physiology, Collingwood, v. 21, n.5, p. 589-602, 1994.

BITENCOURT, J.; MAYER; J. L. S.; ZUFFELATORIBAS, K. C. Propagação vegetativa de Ginkgo biloba por alporquia. Revista Brasileira de Plantas Medicinais, Botucatu, v. 9, n. 2, p. 71-74, 2007.

BOECHAT, C. L.; TEIXEIRA, A. M.; COSTA, A. S. V.; SOUZA, A. P. S. B. Influência de substratos associados à adubação mineral sobre o crescimento inicial de duas cultivares de maracujazeiro-amarelo. Revista Caatinga, Mossoró, v. 23, n. 3, p. 19-25, 2010 . 
BOUMA, T. J.; NIELSON, K. L.; KOUTSAAL, B. Sample preparation and scanning protocol for computerized analysis of root length and diameter. Plant and Soil, Dordrecht, v. 218, n. 1/2, p. 185196, 2000.

CASTRO, L. A. S.; SILVEIRA, C. A. P. Propagação vegetativa do pessegueiro por alporquia. Revista Brasileira de Fruticultura, Jaboticabal, v. 25, n. 2, p. 368-370, 2003.

FRANCO, C.F.; PRADO, R. M. de; BRAGHIROLLI, L. F.; LEAL, R. M.; PEREZ, E.; ROMUALDO, L. M. Uso da poda e de diferentes diâmetros de alporques sobre o desenvolvimento e acúmulo de nutrientes de mudas de lichieira. Revista Brasileira de Fruticultura, Jaboticabal, v. 27, n. 3, p. 491-494, 2005.

HARTMANN, H. T.; KESTER, D. E.; DAVIES JÚNIOR, F. T.; GENEVE, R. L. Plant propagation: principles and practices. $8^{\text {th }}$ ed. New Jersey: Prentice Hall, 2011. 915 p.

LIMA, D. M.; BIASI, L. A.; ZANETTE, F.; ZUFFELLATO-RIBAS, K. C.; BONA, C.; MAYER, J. L. S. Capacidade de enraizamento de estacas de Maytenus muelleri Schwacke com a aplicação de ácido indolbutírico relacionada aos aspectos anatômicos. Revista Brasileira de Plantas Medicinais, Botucatu, v.13, n.4, p.422-438, 2011.

LIMA, D. M.; SILVA, C. L.; RITTER, M.; BIASI, L. A.; ZANETTE, F. ; ZUFFELLATO-RIBAS, K. C. Substratos e auxinas no enraizamento de estacas caulinares de espinheira-santa. Scientia Agraria, Curitiba, v.9, p. 85-89, 2008.
RIOS, E. S.; PEREIRA, M. C.; SANTOS, L. S.; SOUZA, T. C.; RIBEIRO, V. G. Concentrações de ácido indolbutírico, comprimento e época de coleta de estacas, na propagação de umbuzeiro. Revista Caatinga, Mossoró, v. 25, n. 1, p. 52-57, 2012.

RUIZ-SÁNCHEZ, M. C.; PLANA, V.; ORTUÑO, M. F.; TAPIA, L. M.; ABRISQUETA, J. M. Spatial root distribution of apricot trees in different soil till age practices. Plant and Soil, Dordrecht,v. 272, n.1/2, p. 211-221, 2005.

SMARSI, R. C.; CHAGAS, E. A.; REIS, L. L.; OLIVEIRA, G. F.; MENDONÇA, V.; TROPALDI, L.; PIO, R.; FILHO, J. A. S. Concentrações de ácido indolbutírico e tipos de substrato na propagação vegetativa de lichia. Revista Brasileira de Fruticultura, Jaboticabal, v. 30, n. 1, p. 7-11, 2008.

SMART, D. R.; KOCSIS, L.; WALKER, M. A.; STOCKERT, C. Dormant buds and adventitious root formation by Vitis and other woody plants. Journal of Plant Growth Regulation, New York, v. 21, n.4, p. 296-314, 2003.

TAKATA, W.H.S.; NARITA, N.; HOSOMI, S.T.; SUYAMA, J.T.; SILVA, E.G. Alporquia em Lichieira, Litchi chinensis (Sapindaceae), submetida a diferentes doses de ácido naftalenoacético. Acta Biológica Paranaense, Curitiba, v. 40, n. 3/4, p. 109-117. 2011.

YAMANISHI, O. K.; PIRES, M. C.; ALMEIDA, L. F. P. The Brazilian lychee industry - present and future. Acta Horticulturae, The Hague, v. 863, p. 59-65, 2010. 